\title{
INDUKSI EKSPLAN EMBRIO Intsia bijuga SECARA IN VITRO DENGAN MENGGUNAKAN HORMON KINETIN, GA3 DAN IBA
}

\section{(Explants Embryo Induction of Intsia bijuga by In Vitro Using Kinetin, GA3 and IBA Hormones)}

\author{
Andreas Sinuhaji ${ }^{1}$, Julius D. Nugroho ${ }^{1 凶}$ dan Nunang L. May ${ }^{1}$ \\ Jurusan Kehutanan, Fakultas Kehutanan Universitas Papua Manokwari, Papua Barat, \\ 98314. Tlp/Fax: +62986211065. \\ ${ }^{\square}$ Penulis Korespondensi: Email: jd nugroho2004@yahoo.com \\ Diterima: 12 Mar 2017| Disetujui: 18 Apr 2017
}

\begin{abstract}
Abstrak
Penelitian ini bertujuan untuk melihat kesesuaian kombinasi konsentrasi beberapa zat pengatur tumbuh terhadap pertumbuhan embrio Intsia bijuga melalui media tumbuh. Metode yang digunakan dalam penelitian ini adalah eksperimen dengan perhitungan statistik deskriptif melalui ulangan perlakuan sampel. Hasil penelitian menunjukkan bahwa terdapat variasi waktu dari respon kultur embrio Intsia bijuga terhadap media tumbuhnya. Tingkat persentasi hidup eksplan dengan perlakuan MS 0 dan MS + Kinetin 2 ppm memiliki persentasi hidup eksplan 100\%. Namun kontaminasi juga terlihat banyak pada perlakuan media MS + Kinetin 4 ppm + GA3 2 ppm dan media MS + Kinetin 4 ppm + GA3 2ppm + IBA 1 ppm. Adanya kombinasi hormon kinetin dan GA3 akan mendorong pertumbuhan tunas.
\end{abstract}

Kata Kunci: Embrio, Intsia bijuga, hormon pertumbuhan, media tumbuh, perlakuan.

\begin{abstract}
The objective of this study was to reveal the appropriate combination of consentrtion treatment from several growing hormones towards the embryo growth of Intsia bijuga through growth medias. Method applied in the study was experiment by way of descriptive statistical calculation through repetition of the tested samples. The result pointed out that there were variations in responding time of the embryo among growth medias. Life presentation rate of the explants from $M S 0$ and $M S+$ Kinetin 2 ppm treatment had a optimal life presentation of 100\%. However, contaminations have been found a lot in the treatment of $M S+$ Kinetin 4 ppm + GA3 2 ppm and media $M S+$ Kinetin 4 ppm $+G A 3$ $2 p p m+I B A 1 \mathrm{ppm}$. The combination of kinetin and GA3 will accelerate the growth of sprout.
\end{abstract}

Keywords: Embryo, Intsia bijuga, growing hormone, growth media, treatment.

\section{PENDAHULUAN}

Dewasa ini, beberapa tanaman kehutanan telah dieksploitasi sehingga ketersediaan tanaman tersebut di alam semakin menurun, bahkan terancam punah. Salah satu tanaman yang menjadi perhatian saat ini adalah merbau (Intsia spp) yang populasinya semakin terbatas di alam karena adanya eksploitasi dan sulitnya perbanyakan generatif secara alami di alam. Jenis ini memiliki banyak 
kegunaan yaitu sebagai bahan bangunan, lantai, alat - alat rumah tangga, tiang listrik, jembatan dan lain-lain. Melihat banyaknya manfaat dan kegunaan yang diberikan tanaman merbau dan semakin kompleksnya kebutuhan manusia bukan tidak mungkin untuk tahun - tahun ke depan permintaan akan kayu merbau semakin meningkat juga (Sukendro 2010).

Peta hasil olahan Greenpeace menunjukkan bahwa dari seluruh luas hutan yang saat ini menjadi tempat pertahanan terakhir populasi merbau di Pulau Papua 83\% sudah dialokasikan untuk pembalakan komersial, sehingga tinggal $17 \%$ habitat merbau yang masih tumbuh asli dan belum dirusak atau di tebang. Sukendro (2010) memperkirakan bahwa populasi merbau di Indonesia akan punah dalam waktu 35 tahun mendatang, bahkan bisa lebih cepat.

Permudaan alam merbau jarang terdapat karena benih yang jatuh ke tanah sukar berkecambah kecuali jika jatuh di atas tanah yang baik dan mendapat cahaya penuh. Untuk pertumbuhan semai yang optimal di butuhkan cahaya dengan intensitas tinggi dan hal ini akan lebih cepat dibandingan di bawah tajuk tertutup (Sahupala 2005). Berdasarkan kondisi diatas upaya terkait perbanyakan merbau dengan tekhnik non konvensional sangat diperlukan.

Tujuan dari penelitian ini adalah mengetahui konsentrasi kombinasi zat pengatur tumbuh $\mathrm{GA}_{3}$, Kinetin dan IBA untuk pertumbuhan embrio Intsia bijuga dengan menggunakan media media $\mathrm{MS}_{(8)}$ (Murashige dan Skoog) dengan menggunakan tehnik kultur secara in vitro. Manfaat dari penelitian ini adalah sebagai referensi bagi peneliti dan pembaca tentang kombinasi zat pengatur tumbuh untuk perbanyakan tanaman merbau dengan menggunakan eksplan embrio.

\section{METODE PENELITIAN}

Penelitian ini dilakukan di Laboratorium Silvikultur, Fakultas Kehutanan Univeritas Papua, selama 3 bulan. Bahan utama yang digunakan antara lain embrio Intsia bijuga, larutan stock media MS (Murashige \& skoog), zat pengatur tumbuh kinetin, indole butyric acid (IBA) dan Giberelin (GA3).

\section{Metodologi}

Metode yang digunakan dalam penelitian ini adalah metode eksperimen dengan menggunakan perhitungan statistik deskriptif. Penelitian ini terdiri dari 5 perlakuan dan 7 ulangan sehingga didapat 35 satuan percobaan. Perlakuan dari penelitaian ini adalah sebagai berikut A : Media MS 0 (Kontrol) B : Media MS + Kinetin 2 ppm $\mathrm{C}:$ Media MS + Kinetin 2 ppm + GA 32 ppm

$\mathrm{D}:$ Media MS + Kinetin 4 ppm + GA3 2 ppm

$\mathrm{E}:$ Media MS + Kinetin 4 ppm $+\mathrm{GA}_{3} 2$ ppm + IBA 1 ppm.

Data yang diperoleh akan dianalisis dengan menggunakan perhitungan rerata dari setiap perlakuan

\section{Pelaksanaan Penelitian}

1. Sterilisasi Alat dan Bahan

Alat dan bahan yang digunakan pada penelitian ini harus dalam keadaan steril. Sterilisasi bahan menggunakan autoklaf dengan tekanan berkisar antara 15- 20 psi. Cara sterilisasi dengan autoklaf yaitu dengan mengisi air pada autoklaf sampai pada batas yang telah ditetapkan, lalu 
masukkan botol kultur yang berisi ke dalam autoklaf. Tutup autoklaf dengan rapat, lalu dipanaskan setelah tekanan pada autoklaf mencapai $15-20$ psi, maka sterilisasi dilakukan selama 20 menit.

Pada sterilisasi alat yang digunakan adalah oven yang bersuhu $60_{0} \mathrm{C}$. Alatalat yang disterilkan yaitu pingset, gunting, pisau, gelas elemeyer, botol kultur, gelas piala, gelas ukur, cawan petri, pipet tetes, kertas saring. Semua peralatan disterilkan dahulu sebelum digunakan dan pensterilan melalui oven dilakukan semalam atau dengan waktu yang lebih lama untuk memperoleh hasil sterilisasi yang lebih baik.

2. Pembuatan Media

Media yang digunakan pada penelitian ini adalah media dasar Murashige \& Skoog (MS) dengan perlakuan MS 0 (kontrol), Media MS + Kinetin 2 ppm, Media MS + Kinetin 2 ppm + GA3 2 ppm, Media MS + Kinetin 4 ppm + GA3 2 ppm, Media MS + Kinetin 4 ppm + GA3 2 ppm + IBA 1 ppm dan dibuat masing - masing sebanyak $500 \mathrm{ml}$. Tahapan pembuatan media untuk $500 \mathrm{ml}$ yaitu masukan aquades ke dalam gelas piala sebanyak $200 \mathrm{ml}$ lalu, masukan larutan stok A $10 \mathrm{ml}$, Stok B, $10 \mathrm{ml}$, stok C $5 \mathrm{ml}$, Stok D $5 \mathrm{ml}$, Stok E 2,5 ml, stok F 2,5 ml, larutan vitamin 0,5 ppm, gula 15 gram lalu di aduk dengan menggunakan magnetik stirer sampai larut. Tambahkan zat pengatur tumbuh pada masing - masing media tanam dengan konsentrasi yang telah ditetapkan. Tahap selanjutnya yaitu pengukuran $\mathrm{pH}$ larutan dengan menggunakan kertas lakmus dan $\mathrm{pH}$ yang diinginkan yaitu berkisar antara 5,5-5,8. Jika $\mathrm{pH}$ kurang dari 5,5 maka bisa ditambahkan beberapa tetes $\mathrm{NaOH}$ untuk menaikkan tingkatan kebasaan namun, jika $\mathrm{pH}$ lebih dari 5,8 maka kita bisa menambahkan beberapa tetes $\mathrm{HCl}$ untuk menurunkan tingkat keasaman larutan. Tambahkan agar agar murni sebanyak 7,5 g kedalam larutan media tanam lalu tambahkan aquades sampai garis $500 \mathrm{ml}$. Panaskan larutan hingga mendidih sambil diaduk dengan mengunakan magnetik stirer yang juga bisa juga digunakan untuk pemanasan. Setelah mendidih larutan dituang pada masing-masing botol kultur steril masing - masing sebanyak kurang lebih $20 \mathrm{ml}$. Lalu botol ditutup dengan menggunakan plastik transparan dan diikat dengan karet serta dililit dengan plastik seal agar penutupan botol lebih tertutup rapat. Lalu media disterilkan menggunakan autoklaf.

3. Sterilisasi Eksplan

Biji Intsia bijuga dicuci bersih dengan air untuk menghilangkan kotoran yang melekat setelah bersih biji di kocok dengan krolox $100 \%$ selama 20 menit. Kulit biji dilukai lalu direndam dengan air panas dengan suhu $700-800$ hingga kulit merbau yang keras menjadi lebih lunak. Biji kocok kembali dengan krolox 30\% selama 10 menit lalu bilas dengan air steril. Biji yang sudah steril di belah dengan pisau steril guna menggambil embrio yang terdapat pada biji. Embrio yang sudah diperoleh kemudian dikocok dengan betadin lalu tiriskan dengan kertas saring steril.

4. Penanaman Eksplan

Eksplan yang telah steril diambil dengan pingset lalu ditanam pada media tanam yang telah disediakan. Buka tutup plastik botol lalu panaskan lubang botol agar tidak ada kontaminasi oleh bakteri maupun fungi, pingset yang digunakan terlebih dahulu dicelupkan pada alkohol lalu ujung pingset dipanasi oleh api bunsen agar pingset lebih steril. Setelah eksplan ditanam pada media lalu botol 
kembali ditutup dengan palstik dan diikat dengan karet serta dililit kembali dengan plastik warp. Setelah proses selesai dilakukan pada laminar air flow lalu botol kultur ditaru pada rak kultur di ruangan kultur.

5. Pengamatan dan Evaluasi

Pengamatan kultur jaringan ini dilakukan setiap hari untuk melihat perkembangan dari eksplan yang telah ditanam. Dari pengamatan akan tahu berapa banyak ekspaln yang berkecambah dengan baik dan berkecambah pada minggu keberapa maupun eksplan yang terkena kontaminasi.

Variabel Pengamatan:

a. Persen Hidup Eksplan adalah eksplan yang tumbuh $(\%)=\sum$ eksplan yang tumbuh $/ \sum$ semua eksplan yang dikulturkan x 100 .

b. Persen eksplan terkontaminasi adalah eksplan terkontaminasi $(\%)=\Sigma$ eksplan terkontaminasi $/ \sum$ semua eksplan yang dikulturkan x 100 . c. Persen Browing adalah eksplan Browing (\%) $=\sum$ eksplan browing $/ \sum$ semua eksplan yang dikulturkan $\mathrm{x}$ 100.

d. Persen eksplan berakar adalah eksplan berakar $(\%)=\sum$ eksplan berakar $/ \sum$ semua eksplan yang dikulturkan $\mathrm{x}$ 100.

e. Persen eksplan bertunas adalah eksplan bertunas $(\%)=\sum$ eksplan bertunas $/ \sum$ semua eksplan yang dikulturkan x 100 .

f. Persen eksplan memanjang adalah eksplan memanjang $(\%)=\sum$ eksplan memanjang $/ \sum$ semua eksplan yang dikulturkan x 100 .

g. Waktu terbentuknya tunas.

\section{HASIL DAN PEMBAHASAN}

Hasil

Tahapan pertumbuhan dari embrio Intsia bijuga yaitu pemanjangan embrio, perkecambahan, pembentukan akar dan pembentukan tunas. Hasil pengamatan tertera pada Tabel 1 .

Tabel 1. Respon kultur embrio Intsia bijuga yang dikulturkan pada media MS terhadap kombinasi zat pengatur tumbuh.

\begin{tabular}{lccccccc}
\hline \multicolumn{1}{c}{ Perlakuan } & $\begin{array}{c}\text { EH } \\
(\%)\end{array}$ & $\begin{array}{c}\text { EK } \\
(\%)\end{array}$ & $\begin{array}{c}\text { EB } \\
(\%)\end{array}$ & $\begin{array}{c}\text { EM } \\
(\%)\end{array}$ & $\begin{array}{c}\text { EA } \\
(\%)\end{array}$ & $\begin{array}{c}\text { ET } \\
(\%)\end{array}$ & $\begin{array}{c}\text { Waktu } \\
\text { terbentuknya } \\
\text { tunas }\end{array}$ \\
\hline MS 0 & 100 & 0 & 14 & 100 & 71 & 43 & Minggu ke 5 \\
MS + Kin 2 ppm & 100 & 0 & 85 & 71 & 14 & 0 & - \\
MS + Kin 2 ppm + GA3 2 ppm & 86 & 14 & 28 & 71 & 14 & 14 & Minggu ke 3 \\
MS + Kin 4 ppm + GA3 2 ppm & 72 & 28 & 28 & 57 & 0 & 28 & Minggu ke 3 \\
MS + Kin 4 ppm + GA3 2 ppm + & 72 & 28 & 28 & 71 & 0 & 43 & Minggu ke 3 \\
IBA 1 ppm & & & & & & & \\
\hline
\end{tabular}

Keterangan : EH $=$ Eksplan Hidup, EK $=$ Eksplan Kontaminasi, EB $=$ Eksplan Browing, EM = Eksplan Memanjang, EA $=$ Eksplan Berakar, ET $=$ Eksplan Bertunas.

1. Persen Hidup Eksplan Pada perlakuan MS 0 memiliki persen hidup 100\%, media MS + Kinetin 2 ppm memiliki persen hidup 100\%, media MS + Kinetin 2 ppm + GA3 2 ppm memiliki persen hidup 86\%, media MS + Kinetin 4 ppm + GA3 2 ppm memiliki persen hidup 
$72 \%$ dan pada media MS + Kinetin 4 ppm + GA3 2ppm + IBA 1 ppm memiliki persen hidup $72 \%$.

2. Persen Eksplan Terkontaminasi

Beberapa eksplan tidak dapat bertahan hidup dikarenakan tekontaminasi oleh jamur maupun bakteri. Dalam penelitian ini, kontaminasi tidak hanya terjadi pada eksplan melainkan kontaminasi juga terjadi pada media. Media yang telah terkontaminasi akan menghambat pertumbuhan embrio hingga embrio mati (Gambar 1). Pada media MS 0 dan media MS + Kinetin 2 ppm memiliki persen kontaminasi $0 \%$, media $\mathrm{MS}+$ Kinetin $2 \mathrm{ppm}+\mathrm{GA}_{3} 2 \mathrm{ppm}$ memiliki persen kontaminasi $14 \%$, media $\mathrm{MS}+$ Kinetin $4 \mathrm{ppm}+\mathrm{GA}_{3} 2 \mathrm{ppm}$ dan pada media MS + Kinetin $4 \mathrm{ppm}+\mathrm{GA} 3$ $2 \mathrm{ppm}+\mathrm{IBA} 1 \mathrm{ppm}$ memiliki persen kontaminasi

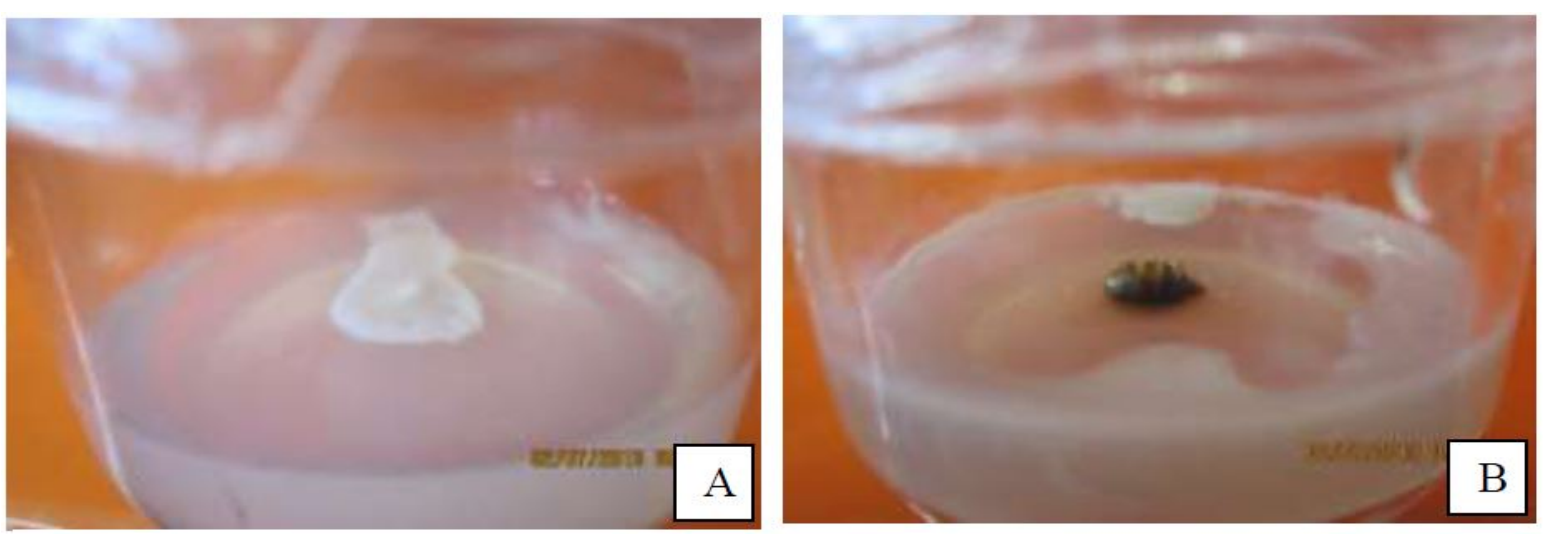

Gambar 1. Kontaminasi yang terjadi pada eksplan dan media pada minggu ke dua. (A) MS + kinetin 4 ppm + GA3 2 ppm + IBA 1 ppm, (B) MS + Kinetin 4 ppm + GA3 2 ppm.

\section{Persen Browning}

Persen browning menunjukkan bahwa perlakuan dengan media MS 0 menghasilkan persen eksplan browning $14 \%$, media MS + Kinetin 2 ppm persen eksplan browning $85 \%$, media MS + Kinetin $2 \mathrm{ppm}+\mathrm{GA}_{3} 2 \mathrm{ppm}$ persen browning 28\%, media MS + Kinetin 4 ppm $+\mathrm{GA}_{3} 2 \mathrm{ppm}$ persen browning 28 dan pada media MS + Kinetin 4 ppm + $\mathrm{GA}_{3} 2 \mathrm{ppm}+$ IBA 1 ppm persen browning 28\%.

4. Persentasi Eksplan Memanjang

Sebelum terbentuknya akar dan tunas, embrio terlebih dahulu mengalami elongasi. Hasil pengamatan menunjukkan bahwa persentasi memanjangnya eksplan pada media MS 0 sebesar $100 \%$, media MS + Kinetin 2 ppm sebesar $71 \%$, media $\mathrm{MS}+$ Kinetin $2 \mathrm{ppm}+\mathrm{GA}_{3} 2 \mathrm{ppm}$ sebesar $71 \%$, media MS + Kinetin 4 ppm $+\mathrm{GA}_{3} 2 \mathrm{ppm}$ sebesar $57 \%$ dan media MS + Kinetin 4 ppm + GA3 2 ppm + IBA 1 ppm memiliki persen eksplan sebesar $71 \%$.

5. Persentasi Eksplan Berakar

Dari hasil pengamatan pada penelitian ini terlihat bahwa tidak semua eksplan menghasilkan akar. Beberapa eksplan hanya mengeluarkan satu akar dan beberapa lainya memiliki cabang cabang akar. Pada perlakuan MS 0 persentasi eksplan berakar $71 \%$, pada perlakuan media MS + Kinetin 2 ppm 
memiliki persen eksplan berakar $14 \%$, pada media MS + Kinetin $2 \mathrm{ppm}+\mathrm{GA}_{3} 2$ ppm memiliki persen eksplan berakar $14 \%$, pada media MS + Kinetin 4 ppm +
GA3 2 ppm memiliki persen eksplan berakar $0 \%$, dan pada media MS + Kinetin $4 \mathrm{ppm}+\mathrm{GA} 32 \mathrm{ppm}+\mathrm{IBA} 1 \mathrm{ppm}$ memiliki persen eksplan berakar $0 \%$.
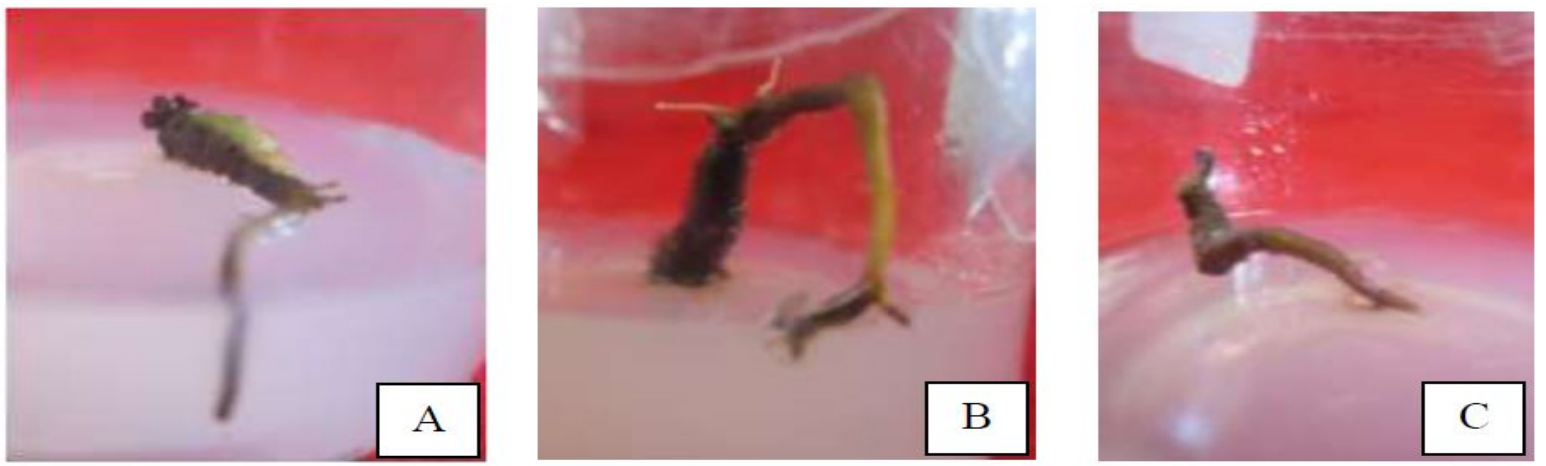

Gambar 2. Pertumbuhan akar pada ekspkan embrio Intsia bijuga pada umur 9 minggu (A) Media MS 0, (B) Media MS + Kinetin 2 ppm, (C) MS + Kinetin 2 ppm + GA3 2 ppm).

6. Persentasi Eksplan Bertunas

Dari hasil pengamatan munculnya tunas pada tiap perlakuan relative beragam. Pada perlakuan MS 0 persentasi eksplan bertunas $43 \%$, pada perlakuan media MS + Kinetin 2 ppm memiliki persentasi eksplan bertunas $0 \%$, pada media MS + Kinetin 2 ppm $+\mathrm{GA}_{3} 2 \mathrm{ppm}$
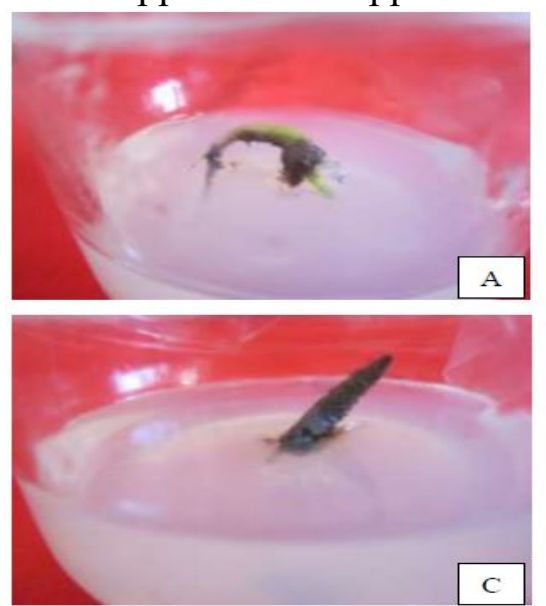

memiliki persentasi eksplan bertunas $14 \%$, pada media MS + Kinetin 4 ppm + GA3 2 ppm memiliki persentasi eksplan bertunas $28 \%$, dan pada media MS + Kinetin $4 \mathrm{ppm}+\mathrm{GA}_{3} 2 \mathrm{ppm}+\mathrm{IBA} 1 \mathrm{ppm}$ memiliki persentasi eksplan bertunas $43 \%$.

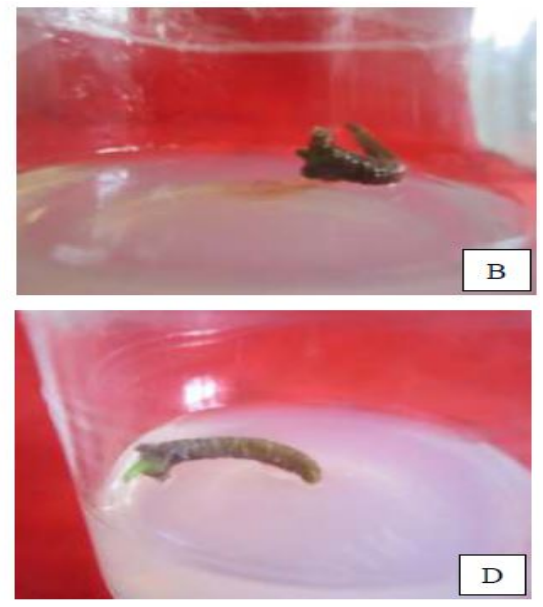

Gambar 3. Petumbuhan tunas eksplan embrio pada umur 9 minggu dalam kultur (A) Media MS 0, (B) MS + Kinetin 2ppm + GA3 2ppm, (C) MS + Kinetin 4ppm + GA3 2ppm, D. MS + Kinetin 4ppm + GA3 2ppm + IBA 1ppm. 


\section{PEMBAHASAN}

Tingkat persentasi hidup eksplan pada penelitian ini terlihat bahwa pada perlakuan MS 0 dan MS + Kinetin 2 ppm memiliki persentasi hidup eksplan $100 \%$. Hal ini terjadi karena tingkat kebersihan eksplan maupun media dan lingkungan sekitar sangatlah baik. Namun, hal tersebut tidak terjadi pada perlakuan yang lainya. Kesterilan pada kegiatan kultur jaringan haruslah diutamakan, karena tingginya tingkat keberhasilan salah satunya dikarenaan minimnya tingkat kontaminasi baik pada eksplan maupun pada media tanam. Pada penelitian ini tingkat kontaminasi yang tinggi di sebabkan oleh bakteri. Kurangnya kebersihan, dapat menyebabkan media tanam yang telah disiapkan terkontaminasi oleh bakteri. Terlihat bahwa kontaminasi banyak terdapat pada perlakuan media MS + Kinetin 4 ppm + $\mathrm{GA}_{3} 2 \mathrm{ppm}$ dan media MS + Kinetin 4 $\mathrm{ppm}+\mathrm{GA} 32 \mathrm{ppm}+\mathrm{IBA} 1 \mathrm{ppm}$ yaitu masing - masing 28\% atau dari 7 ualangan terdapat 2 ulangan terkontaminasi, dan perlakuan media MS 0 dan media MS + Kinetin 2 ppm memiliki persen kontaminasi $0 \%$.

Yuliarti (2010) melaporkan bahwa kontaminasi adalah gangguan yang sangat umum terjadi dalam kegiatan kultur jaringan. Munculnya gangguan ini bisa dipahami sebagai konsekuensi yang sangat wajar atas penggunaan media yang diperkaya. Fenomena kontaminasi ini sangat beragam, dapat dilihat dari jenis kontaminasinya (bakteri, jamur, virus).

Dari hasil pengamatan eksplan embrio yang ditanam pada awalnya akan memanjang terlebih dahulu dan setelah itu akan memunculkan akar dan bertunas, namun hal ini tidak terjadi pada setiap perlakuan. Pada perlakuan MS + Kinetin
$4 \mathrm{ppm}+\mathrm{GA} 32 \mathrm{ppm}+\mathrm{IBA} 1 \mathrm{ppm}$ setelah embrio memanjang tunas akan muncul di minggu ke tiga walaupun akar dari eksplan belum keluar. Pada perlakuan kontrol yaitu MS 0 proses pertumbuhan embrio dimulai dengan pemanjangan embrio, diikuti pertumbuhan akar pada minggu kedua dan tunas pada minggu kelima.

Browning (pencoklatan) adalah suatu keadaan dimana munculnya warna coklat atau hitam pada eksplan atau media tanam karena adanya produksi senyawa phenol. Senyawa tersebut dapat menghambat pertumbuhan dan perkembangan eksplan. Pencoklatan umumnya merupakan tanda adanya kemunduran fisiologi eksplan. Tidak jarang kondisi ini diakhiri dengan kematian eksplan (Yuliarti 2010). Pada penelitian ini persen browning yang paling tinggi terdapat pada perlakuan media MS + Kinetin 2 ppm yaitu sebesar $85 \%$, sedangkan pada perlakuan lain rata - rata persen browning di bawah $30 \%$. Dari hasil ini jelas terlihat bahwa pada perlakuan MS + Kinetin 2 ppm, eksplan atau media tanam banyak memproduksi senyawa phenol. Penggunaan kinetin saja akan mendorong peningkatan produksi senyawa phenol.

Pada perlakuan MS 0 persentasi pertumbuhan akar sangatlah tinggi yaitu $71 \%$, namun setelah penambahan hormon kinetin dengan konsentrasi 2 ppm persentasi pertumbuhan akar menjadi menurun seperti pada perlakuan MS + Kinetin 2 ppm yaitu 14\%. Pada perlakuan berikutnya konsentrasi kinetin di naikan menjadi 4 ppm yaitu MS + Kinetin 4 ppm + GA3 2 ppm dan MS + Kinetin 4 ppm + GA3 2 ppm + IBA 1 ppm, dari perlakuan ini pertumbuhan akar menjadi $0 \%$. dari hasil yang diperoleh terlihat bahwa 
dengan penambahan dan peningkatan konsentrasi hormon kinetin dapat menghambat pertumbuhan akar.

Hormon kinetin menghambat pertumbuhan akar, namun sebaliknya hormon kinetin dengan dikombinasikan dengan hormom $\mathrm{GA}_{3}$ dan IBA terlihat mendorong dalam pembentukan tunas. Pada perlakuan MS 0 persentasi pertumbuhan tunas $43 \%$. Hal ini juga terjadi pada perlakuan MS + Kinetin 4 $\mathrm{ppm}+\mathrm{GA}_{3} 2 \mathrm{ppm}+\mathrm{IBA} 1 \mathrm{ppm}$ yaitu sebesar $43 \%$. Namun, yang membedakan pada 2 perlakuan ini adalah waktu terbentuknya tunas. Pada perlakuan MS 0 tunas muncul pada minggu kelima namun pada perlakuan MS + Kinetin 4 ppm + GA3 $2 \mathrm{ppm}+\mathrm{IBA} 1 \mathrm{ppm}$ tunas muncul pada minggu ketiga. Pada perlakuan MS $0+$ Kinetin 2 ppm tidak menghasilkan tunas.

Persentasi eksplan bertunas pada perlakuan MS + Kinetin 2 ppm yaitu $0 \%$, namun pada perlakuan berikutnya ditambahkan hormon $\mathrm{GA}_{3}$ dengan konsentrasi $2 \mathrm{ppm}$, persentasi esksplan yang bertunas meningkat menjadi $14 \%$. Peran GA3 pada perkecambahan yaitu mempercepat perkecambahan biji dan kuncup tunas, pemajangan batang dan kuncup daun dan diferensiasi akar (Campbell et al. 2003). Selaian elongasi batang, giberelin mengendalikan dari berbagai macam aspek dari perkecambahan, termasuk menghilangkan dormansi dan mobilisasi endosperm cadangan (Lincoln and Eduardo 2002).
Dari hasil penelitian, terlihat jika pada perlakuan hanya terdapat hormone kinetin maka pertumbuhan tunas akan sangat sulit. Oleh karena itu harus dikombinasikan dengan hormon GA3 untuk mendorong pertumbuhan tunas. Dengan penambahan konsentrasi kinetin dari 2 ppm hingga 4 ppm akan menekan pemunculan akar, walaupun dikombinasian dengan GA3 2 ppm dan IBA $1 \mathrm{ppm}$ belum dapat menghasilkan akar. Hal ini bisa diakibatkan karena tingginya konsentrasi hormon kinetin pada tiap-tiap perlakuan.

\section{DAFTAR PUSTAKA}

Campbell NA, Reece JB and Mitchell LG. 2003. Biologi. Alih bahasa: L. Rahayu, EIM Adil, Anita N, Andri, WF Wibowo, W Manalu. Penerbit Erlangga. Jakarta.

Lincoln and Eduardo. 2002. Plant physiology. Sinauer Associate, Inc, Publishers. Sunderland.

Sahapula 2005. Karakteristik dari pohon merbau (Intsia bijuga O.K) http://www.irwantoshut.net/intsia bij uga merbau.html. 16 April 2013 22:33:17.

Sukendro. 2010. Studi pembiakan vegetatif Intsia bijuga (Colebr.) O.K. melalui grafting. Jurnal Silvikultur Tropika. IPB. Bogor.

Yuliarti N. 2010. Kultur jaringan tanaman Skala rumah tangga. Lyli Publisher. Yogyakarta. 